IZA DP No. 4182

Corruption and the Shadow Economy: A Structural Equation Model Approach

Andreas Buehn

Friedrich Schneider

May 2009 


\title{
Corruption and the Shadow Economy: A Structural Equation Model Approach
}

\author{
Andreas Buehn \\ Technische Universitaet Dresden \\ Friedrich Schneider \\ Johannes Kepler University of Linz \\ and IZA
}

Discussion Paper No. 4182

May 2009

IZA

P.O. Box 7240

53072 Bonn

Germany

Phone: +49-228-3894-0

Fax: +49-228-3894-180

E-mail: iza@iza.org

Any opinions expressed here are those of the author(s) and not those of IZA. Research published in this series may include views on policy, but the institute itself takes no institutional policy positions.

The Institute for the Study of Labor (IZA) in Bonn is a local and virtual international research center and a place of communication between science, politics and business. IZA is an independent nonprofit organization supported by Deutsche Post Foundation. The center is associated with the University of Bonn and offers a stimulating research environment through its international network, workshops and conferences, data service, project support, research visits and doctoral program. IZA engages in (i) original and internationally competitive research in all fields of labor economics, (ii) development of policy concepts, and (iii) dissemination of research results and concepts to the interested public.

IZA Discussion Papers often represent preliminary work and are circulated to encourage discussion. Citation of such a paper should account for its provisional character. A revised version may be available directly from the author. 
IZA Discussion Paper No. 4182

May 2009

\section{ABSTRACT}

\section{Corruption and the Shadow Economy: A Structural Equation Model Approach}

The relationship between corruption and the shadow economy is not clear. Theoretically, they either substitute or complement each other - exhibiting either a negative or positive relationship. This paper - using a structural equation model with two latent variables extracts information on various dimensions of corruption and the shadow economy to contribute to the debate on their relationship. It presents empirical evidence of a positive relationship between the shadow economy and corruption. The results show that the shadow economy influences corruption more than corruption influences the shadow economy.

JEL Classification: $\quad$ O17, O5, D78, H11, H26

Keywords: $\quad$ shadow economy, corruption, SEM models

Corresponding author:

Friedrich Schneider

Department of Economics

Johannes Kepler University of Linz

A-4040 Linz-Auhof

Austria

E-mail: friedrich.schneider@jku.at 


\section{Introduction}

Corruption and the existence of shadow economies are known but difficult to measure. What little evidence is available comes from surveys of leading international organizations, such as the World Bank. The accuracy of survey data is questionable, however, due to the delicate nature of topics such as bribery and/or illegal sources of income. Interviewees are not likely to provide truthful responses to questions like, "Did you yourself carry out any undeclared activities in the last 12 months?” or, "How much did you receive or pay in bribes last year?”

Many researchers analyze corruption and the shadow economy independently of each other. Less research is done explicitly addressing the relationship between corruption and the shadow economy using empirical methods. From a theoretical standpoint corruption can either substitute or complement the shadow economy, but the precise nature of the relationship is not clear. This paper analyzes the link between corruption and the shadow economy empirically using a structural equation model (SEM). By modeling the two concepts as latent variables, we contribute to the debate on whether the shadow economy increases or decreases corruption and how corruption affects the shadow economy.

In their influential paper, Shleifer and Vishny (1993) consider two corruption scenarios: corruption in a centralized bureaucracy and corruption in a decentralized bureaucracy. They find that a centralized bureaucracy reduces corruption because bureaucrats in a centralized bureaucracy take the negative impact of their actions on other bureaucrats into account when maximizing the amount of bribes. A decentralized economy, on the other hand, increases corruption because bureaucrats do not take this externality into consideration. More recent papers explore the link between corruption in the official economy and the size of the shadow economy. Johnson, Kaufmann, and Shleifer (1997) present a full-employment model in which individuals are employed either in the official or in the shadow economy. In this model, the shadow economy is a substitute for the official economy and exhibits a negative 
relationship, i.e., an increase in the shadow economy results in a decrease in the official economy. Higher corruption in the official economy increases the size of the shadow economy - which functions like a tax on firms in the official economy and drives them underground. Hindriks, Muthoo, and Keen (1999) - in a model in which taxpayers collude with tax inspectors - also find a positive (complementary) relationship between corruption and the shadow economy (see also Johnson, Kaufmann, and Zoido-Lobatón, 1998b, and Friedman et al., 2000).

Choi and Thum (2005) present a model in which the entrepreneur's option to go underground constrains the corrupt bureaucrat's ability to ask for bribes. The shadow economy mitigates distortions in the official economy and disables bureaucrats from realizing personal gains. The existence of the shadow economy thus reduces corruption, e.g. bribes. Dreher, Kotsogiannis, and McCorriston (2005) extend this model by specifying institutional quality, whereby higher institutional quality reduces the shadow economy. The effect of institutional quality on corruption is ambiguous and depends on the effectiveness of anticorruption measures. Dreher Kotsogiannis, and McCorriston (2005) also show that corruption and the shadow economy are substitutes as the shadow economy imposes constraints on bureaucrats: when firms have the option of going underground, bureaucrats reduce the equilibrium level of bribes. Thus, similar to the findings of Choi and Thum (2005), corruption is lower in the presence of a shadow economy.

In a recent paper, Echazu and Bose (2008) widen the analysis of Shleifer and Vishny (1993) and consider corrupt bureaucrats in the official and shadow economies. While horizontal (sectoral) centralization - in which two different bureaucrats participate in both the official and the shadow economy - lowers corruption, vertical centralization - in which one bureaucrat is charged with monitoring activities in the official and shadow economies increases corruption. This more in-depth analysis confirms the findings of Shleifer and 
Vishny (1993) but contradicts the findings of Choi and Thum (2005). That is, centralization across the two sectors may increase corruption and reduce the size of the official economy. Thus, the official economy does not complement the shadow economy as it does in Choi and Thum (2005).

Since the relationship between corruption and the shadow economy is ambiguous from a theoretical point of view, empirical investigations can make an interesting contribution to the literature. While Dreher, Kotsogiannis, and McCorriston (2005) focus on the impact of institutional quality, Dreher and Schneider (2006) analyze corruption and the shadow economy using panel data. They find mixed evidence depending on the indicators chosen and the specification employed. We model corruption and the shadow economy as unobservable variables using a structural equation model with two latent variables and several causes and indicators. This approach has two main advantages over models in the existing literature. First, it extracts information from different dimensions of the shadow economy and corruption, enabling better estimation of the unobservable, multidimensional variables. Second, the structural equation model reveals the link between the two unobservable variables. To our knowledge, we are the first to analyze directly whether they exhibit a negative relationship - as shown in Choi and Thum (2005) - or a positive relationship - as shown in Johnson, Kaufmann, and Shleifer (1997) or Echazu and Bose (2008).

The remainder of the paper is organized as follows. Section 2 defines the shadow economy and corruption. Section 3 introduces the structural equation model. Sections 4 and 5 discuss the causes and indicators of the shadow economy and of corruption, respectively. Section 6 presents the empirical application and the results. Section 7 concludes. 


\section{Defining the Shadow Economy and Corruption}

\subsection{The Shadow Economy}

The shadow economy is an unobservable economic phenomenon, and no consensus exists as to the definition of the shadow economy. ${ }^{1}$ For example, Smith (1994, p. 18) defines it as "market-based production of goods and services, whether legal or illegal, that escapes detection in official estimates of GDP.” Broader definitions of the shadow economy refer to economic activities - and income earned from them - that circumvent government regulation, taxation, or observation. Table 1 presents a classification which is helpful to develop a reasonable understanding of the shadow economy.

From Table 1, it is clear that the shadow economy includes unreported income from otherwise official trade in goods and services, e.g. through monetary or barter transactions. Thus, all economic activities that would generally be taxable were they reported to governmental (tax) authorities are part of the shadow economy. This paper uses the following, more narrow definition of the shadow economy: all market-based, lawful trade in goods and services deliberately concealed from public authorities in order to evade:

(1) payment of income, value added or other taxes, respectively;

(2) payment of social security taxes;

(3) certain legal labor market standards, such as minimum wages, maximum working hours, safety standards, etc.; or,

(4) compliance with administrative procedures, such as filling out paperwork.

This paper does not consider illegal shadow economic activities, such as burglary, robbery, or drug dealing.

\footnotetext{
${ }^{1}$ This paper does not discuss aspects of measuring shadow economic activities. For an excellent survey on different measurement methodologies, see Schneider and Enste (2000, 2002).
} 


\begin{tabular}{|c|c|c|c|c|}
\hline Type of activity & \multicolumn{2}{|c|}{ Monetary transactions } & \multicolumn{2}{|c|}{ Non-monetary transactions } \\
\hline \multirow[t]{2}{*}{ Illegal activities } & \multicolumn{2}{|c|}{$\begin{array}{l}\text { Trade in stolen goods, drug dealing } \\
\text { and manufacturing, prostitution, } \\
\text { gambling, smuggling, fraud, etc. }\end{array}$} & \multicolumn{2}{|c|}{$\begin{array}{l}\text { Barter of drugs, stolen goods, } \\
\text { smuggling, etc., production or } \\
\text { growing of drugs for own use, } \\
\text { theft for own use. }\end{array}$} \\
\hline & Tax evasion & Tax avoidance & Tax evasion & Tax avoidance \\
\hline Legal activities & $\begin{array}{l}\text { Unreported } \\
\text { income from self- } \\
\text { employment, } \\
\text { wages, salaries } \\
\text { and assets from } \\
\text { unreported work } \\
\text { related to official/ } \\
\text { lawful goods and } \\
\text { services. }\end{array}$ & $\begin{array}{l}\text { Employee } \\
\text { discounts, fringe } \\
\text { benefits. }\end{array}$ & $\begin{array}{l}\text { Barter of } \\
\text { official/lawful } \\
\text { goods and } \\
\text { services. }\end{array}$ & $\begin{array}{l}\text { All do-it- } \\
\text { yourself work } \\
\text { and neighbourly } \\
\text { help. }\end{array}$ \\
\hline
\end{tabular}

Note: The Structure of the table is taken from Lippert and Walker $(1997$, p. 5) with additional remarks.

\subsection{Corruption}

Corruption - like the shadow economy - involves illegal activity. The most general definition of corruption is: the abuse of public power for private gains. The World Bank provides a narrower description: “[corruption] distorts the rule of law, weakens a nation's institutional foundation, and severely affects the poor who are already the most disadvantaged members of our society." Consequently, corruption is "among the greatest obstacles to economic and social development” (Word Bank, 2009). Fighting corruption substantially improves economic performance.

There are numerous costs associated with corruption. First, corruption is a major obstacle to democracy as institutions lose legitimacy when they are used for private advantage. Second, corrupt bureaucrats often redistribute (scarce) public resources to high- 
profile projects at the expense of less spectacular - but vital - public infrastructure projects such as schools and hospitals. Third, corruption hinders the development of fair market structures and distorts competition. Fourth, although the political and economic costs of corruption are severe, the most damaging cost affects the structure of society: corruption undermines people's trust in institutions and political leadership which, in turn, allows unscrupulous leaders to turn national assets into personal wealth. When demanding and paying bribes is socially acceptable, those who are unwilling to comply often emigrate draining the country of its most able and honest citizens (Transparency International, 2009).

\section{A Structural Equation Model for Corruption and the Shadow Economy}

While international organizations like the World Bank require developing countries to fight corruption, anti-corruption measures may be ineffective if the reciprocal relationship between corruption and the shadow economy is not addressed. Plausible policy recommendations must take this link into account. A structural equation model (SEM) can provide useful information about the relationship between corruption and the shadow economy. The SEM models corruption and the shadow economy as two distinct latent variables and explores their relationship using the covariance structures between these latent variables' observable causes and indicators.

Formally, the SEM consists of two parts: the structural equation model and the measurement model. The structural equation model can be represented by:

$$
\boldsymbol{\eta}=\mathbf{B} \boldsymbol{\eta}+\boldsymbol{\Gamma x}+\varsigma
$$

where each $x_{i}, i=1, \ldots, q$ in vector $\mathbf{x}^{\prime}=\left(x_{1}, x_{2}, \ldots, x_{q}\right)$ is a potential cause of one of the two latent variables contained in vector $\boldsymbol{\eta}$. The individual coefficients $\boldsymbol{\gamma}^{\prime}=\left(\gamma_{1}, \gamma_{2}, \ldots, \gamma_{q}\right)$ in matrix $\boldsymbol{\Gamma}$ describe the relationships between the latent variables and their causes. Each latent variable is determined by a set of exogenous causes. The error terms in vector $\varsigma$ represent the 
unexplained components, the covariance matrix for which is abbreviated by $\boldsymbol{\Psi}$. $\boldsymbol{\Phi}$ is the $(q \times q)$ covariance matrix of the causes. The coefficient matrix $\mathbf{B}$ shows the influence of the two latent variables on each other, i.e., the influence of the shadow economy on corruption and vice versa.

The measurement model links the latent variable to its multiple observable indicators, i.e., it is assumed that the latent variable determines its indicators. The measurement model provides information that single-indicator models do not. It is specified by:

$$
\mathbf{y}=\Lambda \eta+\varepsilon,
$$

where $\mathbf{y}^{\prime}=\left(y_{1}, y_{2}, \ldots, y_{p}\right)$ is the vector of indicators for corruption and the shadow economy, $\boldsymbol{\Lambda}$ is a matrix of regression coefficients, and $\boldsymbol{\varepsilon}$ is a $(p \times 1)$ vector of white noise disturbances, the $(p \times p)$ covariance matrix for which is given by $\boldsymbol{\Theta}_{\varepsilon}$.

The model's parameters are estimated using the information contained in the observed variables' variance and covariance matrices. ${ }^{2}$ Thus, the goal of the estimation procedure is to find values for the parameters and covariances that produce an estimate for the SEM model's covariance matrix $\Sigma(\theta), \hat{\Sigma}=\Sigma(\hat{\theta})$ that most closely corresponds to the sample covariance matrix of the observed causes and indicators. Having tested the hypotheses about the theoretical relationships between the latent variables and their causes and indicators, the relationship between corruption and the shadow economy can be analyzed. Figure 1 displays the SEM model used to analyze the relationship between corruption and the shadow economy.

\footnotetext{
${ }^{2}$ For a detailed description of the methodology, see Bollen (1989).
} 


\section{Causes}

Indicators

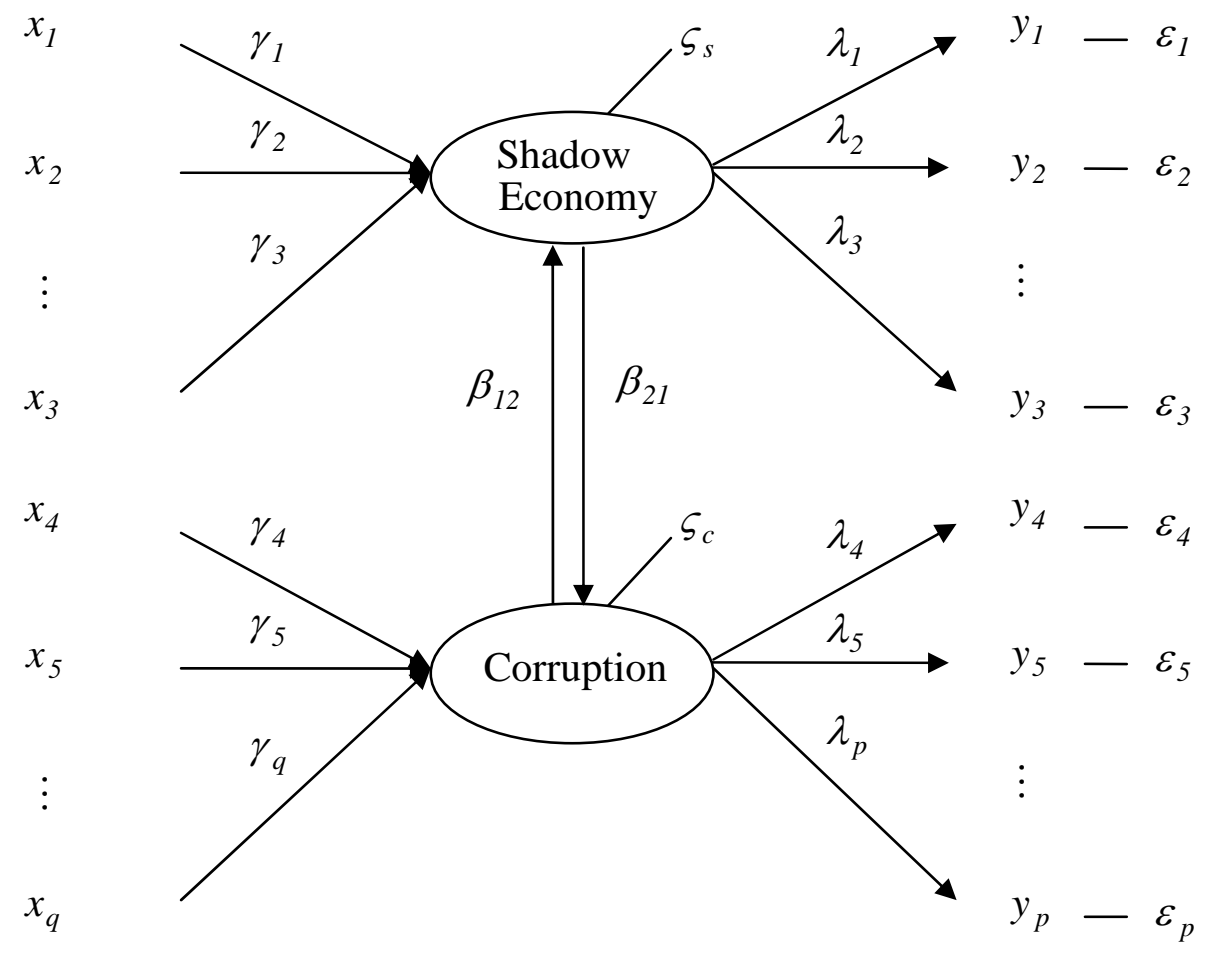

Figure 1. The Structural Equation Model

The model has the following matrix notation:

$$
\left[\begin{array}{l}
\eta_{1} \\
\eta_{2}
\end{array}\right]=\left[\begin{array}{cc}
0 & \beta_{12} \\
\beta_{21} & 0
\end{array}\right] \cdot\left[\begin{array}{l}
\eta_{1} \\
\eta_{2}
\end{array}\right]+\left[\begin{array}{ccccccc}
\gamma_{1} & \gamma_{2} & \gamma_{3} & 0 & 0 & \cdots & 0 \\
0 & 0 & 0 & \gamma_{4} & \gamma_{5} & \cdots & \gamma_{q}
\end{array}\right] \cdot\left[\begin{array}{c}
x_{1} \\
x_{2} \\
x_{3} \\
x_{4} \\
x_{5} \\
\vdots \\
x_{q}
\end{array}\right]+\left[\begin{array}{c}
\varsigma_{1} \\
\varsigma_{2}
\end{array}\right],
$$




$$
\left[\begin{array}{c}
y_{1} \\
y_{2} \\
y_{3} \\
y_{4} \\
y_{5} \\
\vdots \\
y_{p}
\end{array}\right]=\left[\begin{array}{cc}
1 & 0 \\
\lambda_{2} & 0 \\
\lambda_{3} & 0 \\
0 & 1 \\
0 & \lambda_{5} \\
\vdots & \vdots \\
0 & \lambda_{p}
\end{array}\right] \cdot\left[\begin{array}{l}
\eta_{1} \\
\eta_{2}
\end{array}\right]+\left[\begin{array}{c}
\varepsilon_{1} \\
\varepsilon_{2} \\
\varepsilon_{3} \\
\varepsilon_{4} \\
\varepsilon_{5} \\
\vdots \\
\varepsilon_{p}
\end{array}\right],
$$

where $\eta_{1}$ and $\eta_{2}$ are the latent variables for the shadow economy and corruption, respectively. Equations (3) and (4) represent the structural and measurement models, respectively. The estimation of the parameters $\beta_{12}$ and $\beta_{21}$ in the SEM model explain the relationship between the two latent variables $\eta_{1}$ and $\eta_{2}$, i.e., between the shadow economy and corruption. $\beta_{12}$ describes the effect of $\eta_{1}$ (the shadow economy) on $\eta_{2}$ (corruption) while $\beta_{21}$ describes the effect of $\eta_{2}$ (corruption) on $\eta_{1}$ (the shadow economy).

\section{Causes and Indicators of the Shadow Economy}

\subsection{Causes of the Shadow Economy}

\subsubsection{Tax Burden}

The selection of the shadow economy's causes is based on theoretical and empirical evidence found in the literature. For example, high social security and other taxes are important causes of the shadow economy. ${ }^{3}$ Taxes affect labor-leisure choices and stimulate the labor supply in the shadow economy. The greater the difference between the total cost of labor in the official economy and the unofficial (shadow) economy or when after-tax earnings from work in the official economy do not exceed earnings from work in the unofficial economy, the greater is the incentive to work in the shadow economy.

\footnotetext{
${ }^{3}$ See Thomas (1992), Schneider (1986, 1997, 2003, 2005), Johnson, Kaufmann, and Zoido-Lobatón (1998a,b), Tanzi (1999), Giles, Tedds, and Werkneh (2002), and Dell’Anno and Schneider (2003).
} 
Neck, Hofreither, and Schneider (1989) analyze this relationship theoretically. They find that - under an additive-separable utility function and a two-stage decision setup of the consumer - higher marginal (income) tax rates imply greater labor supply in the shadow economy. Schneider (1994b, 2000) and Johnson, Kaufmann, and Zoido-Lobatón (1998a,b) provide statistically significant empirical evidence that higher taxes have a positive effect on the shadow economy.

Unfortunately, information about marginal tax rates is not typically available on a broad basis. When government spending increases relative to private spending or when the government redistributes income by raising social security and other taxes, individual freedom vis-à-vis spending decisions is reduced. The substitution of political choice over private choice, i.e. higher government expenditure and/or taxes creates an incentive for individuals to work in the shadow economy. We use government consumption, the size of government, and transfers and subsidies as variables to measure the influence of government on the size of the shadow economy. ${ }^{4}$ We hypothesize that:

(1) The more countries rely on the political process to redistribute income - i.e., the higher the tax rate and, thus, the lower individual economic freedom - the larger the shadow economy, ceteris paribus.

\subsubsection{Intensity of Regulation}

The intensity of regulation is another important cause for the existence of the shadow economy. Examples of regulations include labor market regulations, such as minimum wages and hiring/firing regulations, licensing restrictions, and trade barriers. The intensity of regulation can be measured by the total number of laws and regulations, the size of staff at

\footnotetext{
${ }^{4}$ We are restricted to these indirect measures of social security and other taxes in the empirical analysis because using more direct measures, such as tax revenues or social security contributions as a percentage of official GDP, substantially reduces the sample size.
} 
regulatory agencies, or the total time it takes to start a business. In general, regulations lead to a substantial increase in labor costs in the official economy. Since most of these costs can be shifted onto employees, regulations provide an incentive to work in the shadow economy where these costs can be avoided. An increase in the intensity of regulation also reduces the freedom (of choice) for individuals engaged in the official economy.

The impact of regulation on the shadow economy has been analyzed theoretically as well as empirically. The model of Johnson, Kaufmann, and Shleifer (1997) shows that those countries with a more regulated economy have a larger shadow economy. Significant empirical evidence of the influence of (labor) market regulations on the shadow economy is also presented in Johnson, Kaufmann, and Zoido-Lobatón (1998b). We hypothesize that:

(2) The higher the regulation intensity, the larger the shadow economy, ceteris paribus.

\subsubsection{Labor Market}

Unemployment also affects the size of the shadow economy. While consensus exists that high labor costs cause unemployment in the countries of the Organization for Economic Cooperation and Development (OECD), the impact of high unemployment on the shadow economy is ambiguous. On the one hand, higher unemployment increases the incentive to demand goods and services in the shadow economy - which are often much cheaper. On the other hand, unemployed people have less money to purchase goods and services, even in the shadow economy, so a negative relationship can prevail.

Whether unemployment exhibits a positive or negative relationship with the shadow economy depends on the income and the substitution effect. Income losses due to unemployment reduce demand in both the shadow and official economies. A substitution of official demand for goods and services for unofficial demand takes place as unemployed 
workers turn to the shadow economy - where cheaper goods and services make it easier to countervail utility losses. This behavior may stimulate additional demand in the shadow economy. If the income effect exceeds the substitution effect, a negative relationship develops. Likewise, if the substitution effect exceeds the income effect, the relationship is positive. In developed countries, however, unemployment benefits often offset the loss of income caused by unemployment. Because of the theoretical ambiguity, we do not formulate a hypothesis about the relationship between unemployment - measured by the unemployment rate - and the shadow economy.

\subsection{Indicators of the Shadow Economy}

In addition to the causal variables - which determine the size and development of the shadow economy - three indicator variables are used to make the unobservable shadow economy visible: the ratio of M0 to M1, the growth rate of official gross domestic product (GDP), and the labor force participation rate. As explained in Section 3, the challenge of the measurement part of the structural equation model is to select those indicators that appear to be influenced by the latent variable, ceteris paribus. The three indicator variables selected mirror activities in the shadow economy particularly well, as explained below.

The first indicator is the ratio of M0 to M1. Transactions in the shadow economy are typically carried out using cash as this protects the principal and the agent in their shadow economic activities. Cash holdings thus reflect shadow economic activity. We therefore expect a positive relationship between the shadow economy and currency in circulation and hypothesize that:

(3) The larger the shadow economy, the more cash circulates, ceteris paribus. 
The effects of the shadow economy on resource allocation and, thus, on the official economy are ambiguous. The shadow economy can be seen as positive response to the demand for an entrepreneurial environment and the creation of new markets. The shadow economy can enhance entrepreneurship, increase efficiency and, in turn, stimulate growth in the official economy. Adam and Ginsburgh (1985) derive the positive relationship between the shadow economy and resource allocation theoretically under the assumption of low entry costs and a low probability of enforcement in the shadow economy.

The shadow economy can also be seen as a negative response to high taxation and overregulation. It is often argued, for example, that activities in the shadow economy are not subject to taxation. Shifting them to the official economy leads to an increase in governmental tax revenues - which increases the quality and/or quantity of public goods. As public infrastructure is a key element of economic growth, a larger (smaller) shadow economy reduces (increases) growth in the official economy. Loayza (1996) provides empirical evidence of the negative relationship between the shadow economy and resource allocation. We follow this reasoning and hypothesize that:

(4) The larger the shadow economy, the smaller official GDP growth, ceteris paribus.

The labor force participation rate can also serve as an important indicator of the shadow economy. Changes in the participation rate reflect empirically a flow of resources between the official and the shadow economy. The expected sign of the relationship between the shadow economy and the labor force participation rate is however ambiguous. No consensus exists in the literature as to whether the shadow economy really affects the labor force participation rate. For example, Bajada and Schneider (2005) argue that this is not the 
case while Giles (1998) argues that the labor force participation rate reflects a movement of the workforce from the official to the shadow economy.

Although the labor force participation rate is widely used as indicator of the shadow economy in empirical studies, the expected relationship is debatable. Over the last thirty years, the composition of the labor force has changed considerably. As it is not clear whether changes in the labor force participation rate are caused by changes of the shadow economy or by other reasons, e.g. by a growing female participation in the workforce (Dell’ Anno, 2007), we do not formulate a hypothesis regarding the effect of the shadow economy on the labor force participation rate.

\section{Causes and Indicators of Corruption}

As with the selection of causes and indicators of the shadow economy, the selection of causes and indicators of corruption is based on previous findings of the relevant theoretical and empirical literature. We discuss first the causal variables and then the indicators. For clarity, the causes are grouped into three main categories: political and judicial causes, social and cultural causes, and economic causes.

\subsection{Causes of Corruption}

\subsubsection{Political and Judicial Causes of Corruption}

The political and judicial causes capture a country's democratic and institutional quality and the quality of the political system, respectively. It is widely believed that corruption is related to the deficiencies in the political system and that sound administrative systems, clear rules, and a long tradition of institution-building deter corruption. Promoting political competition and increasing transparency and accountability can reduce the scope for bribery. Other 
characteristics of a country's political system, such as electoral rules and the degree of decentralization, affect corruption (see Shleifer and Vishny, 1993, or Echazu and Bose, 2008).

Political and judicial factors feature prominently in many recent studies of the importance of governance for economic development (see, for example, North, 1990, or Easterly and Levine, 1997). While strong and efficient legal systems protect property rights and provide a stable framework for economic activity, weak legal systems fail to provide such an environment. This undermines market operations, reduces individuals' incentives to participate in productive activities, and encourages unproductive activities like corruption. We therefore hypothesize that:

(5) The lower the quality of the political system and policy formulation and the lower the respect for the rule of law, the higher the level of corruption, ceteris paribus.

\subsubsection{Social and Cultural Causes of Corruption}

Many individuals in poor countries with low literacy rates have little understanding of governmental operations (Rose-Ackerman, 1999). For them, it is often not clear what they should expect from a legitimate government, and corruption results from the tradition that one present gifts to show gratitude for favorable decisions (Pasuk and Sungsidh, 1994). Thus, corruption is less a matter of bargaining than it is of cultural and social exchange. Highly corrupt countries often underinvest in public education (Mauro, 1998) and human capital, thereby perpetuating ignorance of governmental operations. We use the primary school enrollment rate to account for society and culture's influence on corruption and hypothesize that: 
(6) The lower the primary school enrollment rate, the higher the level of corruption, ceteris paribus.

\subsubsection{Economic Causes of Corruption}

Governments often interfere with the economy in terms of the regulatory environment and the fiscal burden imposed on individuals. This interference is said to reduce economic freedom. Greater economic freedom is said to reduce corruption because individuals face more choice in doing business, less red tape, and fewer bureaucratic hassles. ${ }^{5}$ Greater government interference increases corruption - causing both bribe takers and bribe seekers to engage in activities that circumvent rules and regulations.

Tanzi (1998) and Dreher, Kosogiannis, and McCorriston (2007) emphasize the size of the public sector as it offers bureaucrats some degree of discretion in the allocation of goods and services: the more significant the role of the public sector, the higher the level of corruption. Van Rijckeghem and Weder (2001) find that this relationship is stronger when bureaucrats’ wages are relatively low. Treisman’s (2000), however, finds no evidence to support Van Rijckeghem and Weder’s (2001) findings. We hypothesize that:

(7) The lower the economic freedom - i.e., the higher the level of government interference - the higher the level of corruption, ceteris paribus.

\subsection{Indicators of Corruption}

The existing literature offers some guidance with respect to appropriate indicators for corruption. Since it is generally accepted that corruption is what makes poor countries poor, GDP per capita is an obvious choice to indicate corruption. Corruption disrupts economic

\footnotetext{
${ }^{5}$ For more on the influence of economic freedom on corruption, see Bardan (1997) or Goel and Nelson (2005).
} 
development and is seen as responsible for Africa's lasting poverty and Latin America's stagnation. Almost all available evidence suggests that corruption has a negative effect on economic development (see, for example, Mauro, 1995 and Paldam, 2003). We hypothesize that:

(8) The higher the level of corruption, the lower the level of economic development - as measured by per capita GDP, ceteris paribus.

The final set of indicators measures the extent of corruption in a society. A natural choice is to use an index of bribes and extra payments derived from responses to the following question: "In your industry, how commonly would you estimate that firms make undocumented extra payments or bribes?” (Gwartney, Lawson, and Norton, 2008, p. 194). ${ }^{6}$ In addition to the “bribe payers index," we employ a variable that measures judicial independence, i.e., whether the judiciary is impartial to political influence by members of government, lobbyists and special interest groups, and private citizens and/or businesses. We expect a positive correlation between these variables and the latent variable of corruption.

\section{Empirical Application}

\subsection{Data}

In the application of the structural equation model, we consider annual data for 51 countries from 2000 to 2005 . We are restricted to annual data since few of the variables are available at higher frequencies. Also, some of the variables were surveyed only every other year. All data is publicly available and is provided by international organizations such as the World Bank or is taken from published research papers. Table A.1 in the Appendix presents a comprehensive

\footnotetext{
${ }^{6}$ Other variables which fit into this category are corruption indices such as the freedom from corruption index presented in Gwartney, Lawson, and Norton (2008).
} 
overview of the variables, definitions, and data sources.

Among the 51 countries included in the sample, 10 are OECD countries and 6 are nonOECD "high income countries" as defined by the World Bank. ${ }^{7}$ The remaining countries are emerging markets, which can be divided into advanced and secondary emerging markets as suggested by the FTSE Group. ${ }^{8}$ Taking further into account the advanced emerging markets of Brazil and South Africa, altogether, 18 - or more than one-third - of the 51 countries are developed countries while 33 - or less than two-thirds - are developing countries. We conclude that the sample is well-balanced. Appendix provides a complete list of countries included in the sample.

Figure 2 - which plots the size of the shadow economy against the extent of corruption for 45 out of the 51 countries in the sample - provides some preliminary evidence of the relationship between corruption and the shadow economy. To calculate the shadow economy for each country, we average Schneider's (2006) estimates for 2001, 2002, and 2003. To measure the extent of corruption, we average the country's score on Transparency International’s Corruption Perception Index (CPI) for 2001, 2002, and 2003.

As can be seen from Figure 2, the countries can be grouped into two categories: industrialized countries with relatively small shadow economies and low levels of corruption and developing or emerging countries with significant shadow economies and relatively high levels of corruption. The relationship between corruption and the shadow economy appears to be positive for both groups - with the exception of Tunisia and Uruguay in the second group. The latter two countries - though they exhibit shadow economies similar in size to the other countries in their group - are less corrupt. India, Indonesia, and Paraguay are amongst the most corrupt countries in the sample but -compared to the other countries in their group -

\footnotetext{
${ }^{7}$ The World Bank defines "high income countries" as having annual per capita Gross National Incomes (GNI) of $\$ 11,456$ or more. Our classification uses the 2007 per capita GNI.

${ }^{8}$ Advanced emerging markets include upper middle-income countries with advanced market infrastructures or high-income countries with less-developed market infrastructures. In our sample, Brazil and South Africa are treated as advanced emerging markets.
} 
exhibit relatively smalls shadow economies. Figure 2 thus provides some initial proof that corruption and the shadow economy are linked and that the relationship is similar within each group. ${ }^{9}$ Table A.2 in the Appendix lists the countries in rank order according to the CPI, the CPI country score, and the size of the shadow economy for the set of 45 countries for which shadow economy estimates are available.

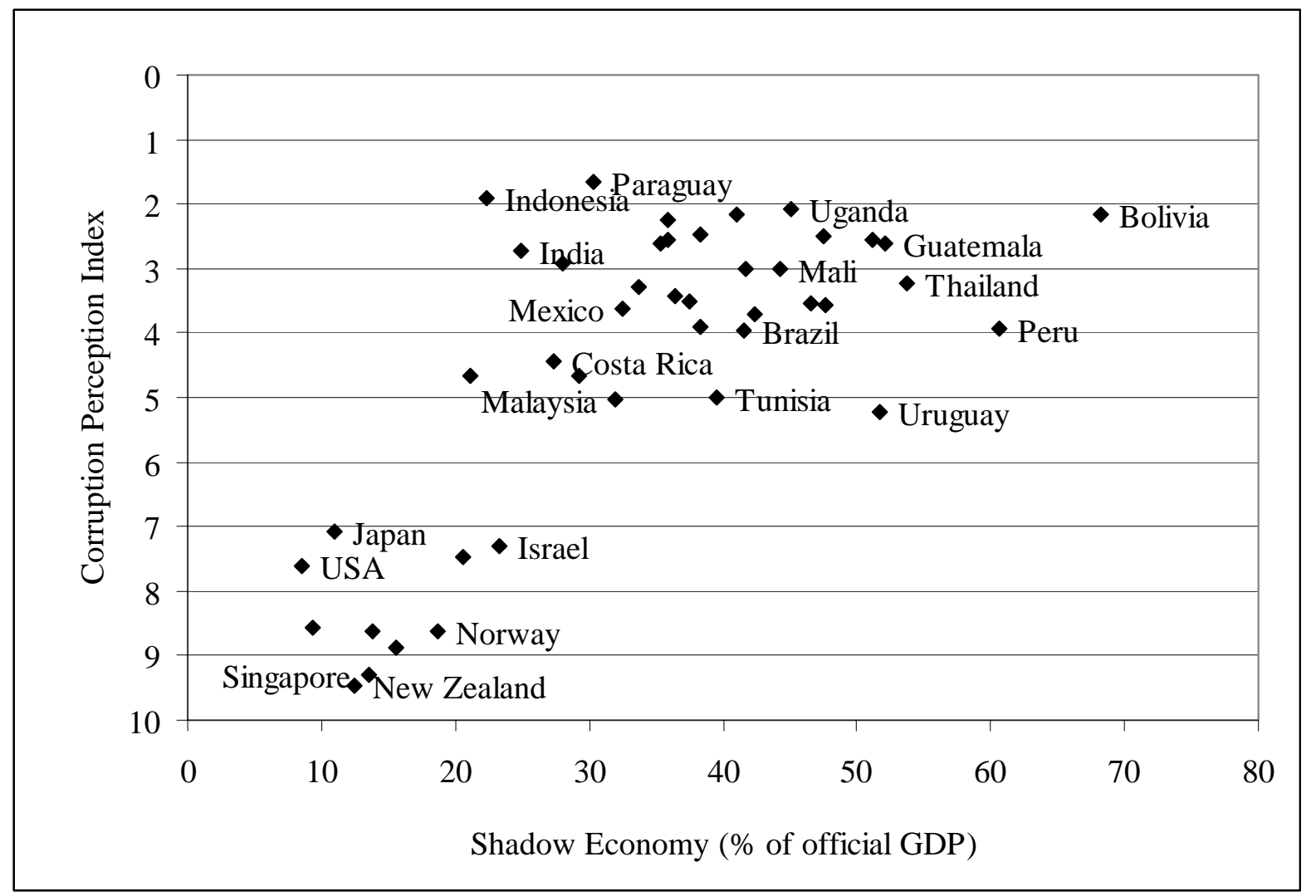

Figure 2. Scatter Plot of the Relationship between Corruption and the Shadow Economy

Note: Both, the CPI Country Score and the shadow economy estimates, taken from Schneider (2006), are average values over the years 2001, 2002, and 2003. Higher values of the CPI index indicate lower levels of perceived corruption in the respective country.

\subsection{Results}

As explained in Section 3, the application of a structural equation model implies that observable variables indicate the shadow economy and corruption. According to the

\footnotetext{
${ }^{9}$ The latter argument is also reflected by an insignificant dummy variable included in the empirical analysis to test for a significant difference between the two groups of countries.
} 
theoretical considerations in Section 4, we employ the growth rate of real GDP, the ratio of the monetary aggregates M0 to M1 as a transaction variable, and the labor force participation rate to make shadow economic activities 'visible'. We expect a positive relationship between the transaction variable and the shadow economy and a negative relationship between the growth rate of GDP and the shadow economy.

We use real GDP per capita, an index measuring the prevalence of bribery, and an index measuring integrity of the judiciary to indicate corruption. We expect a negative relationship between real GDP per capita and corruption since corruption is inversely related to economic development. Since higher scores on the judicial integrity index indicate greater judicial independence, we expect a negative relationship between corruption and the index of judicial integrity. We use the inverse of the bribery index so that the lower the value, the lower the prevalence of bribery. Thus, we expect a positive relationship between corruption and the prevalence of bribery.

We use the unemployment rate of the male population, indices measuring the labor market and business regulations, government consumption, and transfers and subsidies to capture causes of the shadow economy. Government consumption and transfers and subsidies are used to proxy the financial burden resulting from taxes. We expect a positive relationship between the rate of male unemployment and the shadow economy. For the labor market and business regulation indices as well as for government consumption, lower scores indicate greater government interference in the economy. To make the empirical results comparable to our theoretical hypotheses, we transform these indices by using the inverse of the original scores. Thus, we expect a positive relationship between these three variables and the shadow economy.

As explained in Section 5, we explore the political, social, and economic causes of corruption. In our benchmark specification (1) the rule of law and government effectiveness 
are used to capture the political causes of corruption. We expect that greater respect for the rule of law and better institutional quality reduce corruption. A measure for bureaucracy costs is used to capture the economic causes of corruption. For this index, higher scores indicate stricter regulations and, thus, higher bureaucratic costs. Thus, we expect that higher bureaucratic costs increase corruption. Figure 3 shows the structural equation model's path diagram for the benchmark specification whereby the small squares attached to the arrows indicate the expected sign in the empirical analysis.

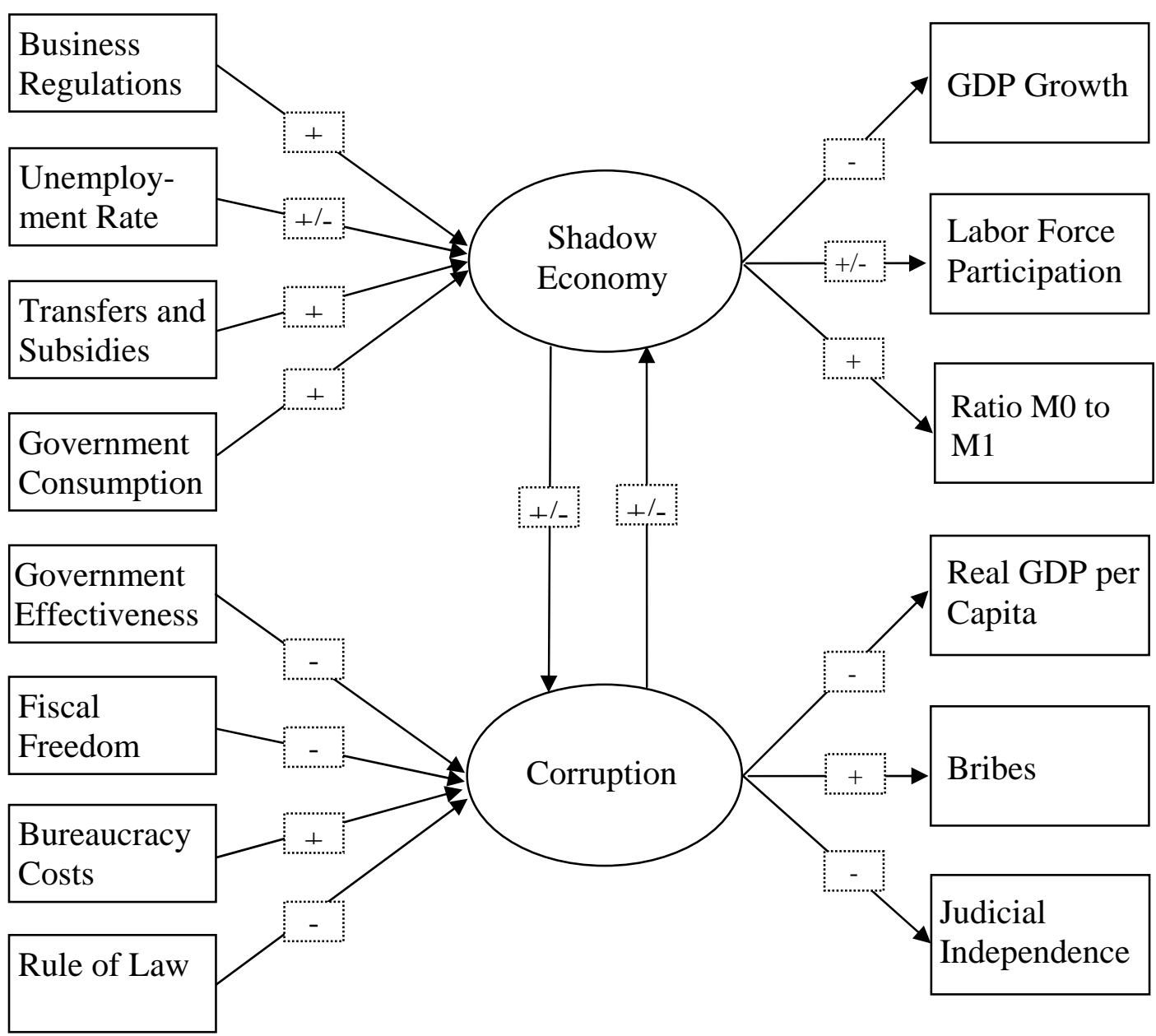

Figure 3. Path Diagram of the Benchmark Model

Once causes and indicators have been selected, the model can be estimated to derive the values for the parameters that link the latent variables to each other and to the causes and 
indicators. Table 2 presents the estimation results. For simplicity, the goodness-of-fit statistics for each specification are presented separately - in Table A.3 in the Appendix.

The following discusses causes and indicators for the shadow economy and for corruption. It is important to note that the identification and estimation of the structural equation model requires the normalization of one of the indicators of each latent variable to an a priori value. Typically, the indicator variable that loads most on the construct represented by the latent variable is used. We therefore set the coefficient of the indicators real GDP growth and real GDP per capita to -1 following our theoretical considerations of Section $4 .{ }^{10}$

Most of the estimated coefficients of the shadow economy's causes are statistically significant at conventional levels and have the theoretically expected sign. The coefficients reveal that business regulations and labor market conditions are the most important determinants of the shadow economy. Specification (2) - in which the unemployment rate is substituted for a direct measure of labor market regulations - confirms this observation. We also find that taxation and redistribution are important - as demonstrated by the significant coefficient of the government consumption variable. This effect is less significant for specification (3) - in which government consumption is substituted for the variable measuring the size of government. The coefficient for the variable 'transfers and subsidies' is not statistically significant.

With regard to the shadow economy's indicators, we find - as hypothesized - a positive relationship between the shadow economy and the transaction measure. We find negative relationships between the shadow economy and the growth rate of real GDP and between the shadow economy and the labor force participation rate. Our findings confirm the findings of other theoretical and empirical papers.

\footnotetext{
10 This is a convenient and widely accepted method of normalization which does not affect the qualitative results. For more details, see Bollen (1989).
} 
Table 2. Estimation Results (Standardized Coefficients)

\begin{tabular}{|c|c|c|c|c|c|c|c|c|c|c|}
\hline Specification & (1) & & $(2)$ & & (3) & & $(4)$ & & (5) & \\
\hline Latent Variables & $\mathrm{SE}$ & $\mathrm{C}$ & SE & $\mathrm{C}$ & $\mathrm{SE}$ & $\mathrm{C}$ & $\mathrm{SE}$ & $\mathrm{C}$ & $\mathrm{SE}$ & $\mathrm{C}$ \\
\hline \multicolumn{11}{|l|}{ Causes } \\
\hline Business Regulations & $\begin{array}{l}0.18^{* *} \\
(2.00)\end{array}$ & & $\begin{array}{l}0.13^{*} \\
(1.84)\end{array}$ & & $\begin{array}{l}0.21^{* *} \\
(2.18)\end{array}$ & & $\begin{array}{l}0.18 * * \\
(2.02)\end{array}$ & & $\begin{array}{l}0.18 * * \\
(1.98)\end{array}$ & \\
\hline Unemployment & $\begin{array}{l}0.19 * * \\
(1.98)\end{array}$ & & & & $\begin{array}{l}0.16^{*} \\
(1.78)\end{array}$ & & $\begin{array}{l}0.17^{*} \\
(1.93)\end{array}$ & & $\begin{array}{l}0.20 * * \\
(2.02)\end{array}$ & \\
\hline Transfers and Subsidies & $\begin{array}{l}0.09 \\
(1.16)\end{array}$ & & $\begin{array}{l}0.05 \\
(1.09)\end{array}$ & & $\begin{array}{l}0.11 \\
(1.35)\end{array}$ & & $\begin{array}{l}0.09 \\
(1.22)\end{array}$ & & $\begin{array}{l}0.09 \\
(1.15)\end{array}$ & \\
\hline Government Consumption & $\begin{array}{l}0.16^{* *} \\
(1.98)\end{array}$ & & $\begin{array}{l}0.11^{*} \\
(1.76)\end{array}$ & & & & $\begin{array}{l}0.15^{*} \\
(1.91)\end{array}$ & & $\begin{array}{l}0.17 * * \\
(2.05)\end{array}$ & \\
\hline Labor Market Regulations & & & $\begin{array}{l}0.22 * * \\
(2.05)\end{array}$ & & & & & & & \\
\hline Size of Government & & & & & $\begin{array}{l}0.14^{*} \\
(1.66)\end{array}$ & & & & & \\
\hline Government Effectiveness & & $\begin{array}{l}-0.22 * * * \\
(3.13)\end{array}$ & & $\begin{array}{l}-0.15^{* *} \\
(2.25)\end{array}$ & & $\begin{array}{l}-0.20 * * * \\
(2.66)\end{array}$ & & $\begin{array}{l}-0.23 * * * \\
(3.36)\end{array}$ & & $\begin{array}{l}-0.21 * * * \\
(3.01)\end{array}$ \\
\hline Fiscal Freedom & & $\begin{array}{l}-0.15^{* * *} \\
(2.48)\end{array}$ & & $\begin{array}{l}-0.09 * \\
(1.81)\end{array}$ & & $\begin{array}{l}-0.15^{* * *} \\
(2.27)\end{array}$ & & $\begin{array}{l}-0.14^{* *} \\
(2.37)\end{array}$ & & $\begin{array}{l}-0.17 * * * \\
(2.68)\end{array}$ \\
\hline Bureaucracy Costs & & $\begin{array}{l}0.42 * * * \\
(5.15)\end{array}$ & & $\begin{array}{l}0.34 * * * \\
(2.95)\end{array}$ & & $\begin{array}{l}0.41^{* * *} \\
(4.29)\end{array}$ & & $\begin{array}{l}0.40 * * * \\
(4.79)\end{array}$ & & $\begin{array}{l}0.45 * * * \\
(5.52)\end{array}$ \\
\hline Rule of Law & & $\begin{array}{l}-0.01 \\
(0.10)\end{array}$ & & $\begin{array}{l}0.01 \\
(0.19)\end{array}$ & & $\begin{array}{l}-0.01 \\
(0.09)\end{array}$ & & & & $\begin{array}{l}-0.02 \\
(0.38)\end{array}$ \\
\hline School Enrollment & & & & & & & & $\begin{array}{l}0.06 \\
(1.01)\end{array}$ & & \\
\hline
\end{tabular}




\begin{tabular}{|c|c|c|c|c|c|}
\hline Specification & (1) & (2) & (3) & (4) & (5) \\
\hline Latent Variables & SE & SE & SE & SE & $\mathrm{SE}$ \\
\hline \multicolumn{6}{|l|}{ Indicators } \\
\hline GDP Growth & -0.51 & -0.47 & -0.46 & -0.50 & -0.51 \\
\hline Labor Force Participation & $\begin{array}{l}-0.41 * * * \\
(4.15)\end{array}$ & $\begin{array}{l}-0.44 * * * \\
(4.02)\end{array}$ & $\begin{array}{l}-0.43^{* * *} \\
(4.04)\end{array}$ & $\begin{array}{l}-0.41 * * * \\
(4.13)\end{array}$ & $\begin{array}{l}-0.40 * * * \\
(4.15)\end{array}$ \\
\hline Ratio M0 to M1 & $\begin{array}{l}0.31 * * * \\
(3.33)\end{array}$ & $\begin{array}{l}0.34 * * * \\
(3.33)\end{array}$ & $\begin{array}{l}0.35 * * * \\
(3.52)\end{array}$ & $\begin{array}{l}0.32 * * * \\
(3.36)\end{array}$ & $\begin{array}{l}0.30 * * * \\
(3.32)\end{array}$ \\
\hline Real GDP per Capita & -0.78 & -0.75 & -0.74 & -0.78 & -0.77 \\
\hline Bribes & $\begin{array}{l}0.15^{*} \\
(1.73)\end{array}$ & $\begin{array}{l}0.16^{* *} \\
(1.99)\end{array}$ & $\begin{array}{l}0.16^{*} \\
(1.95)\end{array}$ & $\begin{array}{l}0.15^{* *} \\
(1.74)\end{array}$ & $\begin{array}{l}0.14^{*} \\
(1.71)\end{array}$ \\
\hline Judicial Independence & $\begin{array}{l}-0.06 \\
(0.73)\end{array}$ & $\begin{array}{l}-0.08 \\
(0.99)\end{array}$ & $\begin{array}{l}-0.07 \\
(0.80)\end{array}$ & $\begin{array}{l}-0.06 \\
(0.71)\end{array}$ & \\
\hline Freedom from Corruption & & & & & $\begin{array}{l}0.12 \\
(1.46) \\
\end{array}$ \\
\hline \multicolumn{6}{|l|}{ Latent variables } \\
\hline $\begin{array}{l}\text { Shadow Economy } \rightarrow \\
\text { Corruption }\end{array}$ & $\begin{array}{c}0.68 * * * \\
(4.23)\end{array}$ & $\begin{array}{c}1.07 * * * \\
(4.34)\end{array}$ & $\begin{array}{c}0.81^{* * *} \\
(3.98)\end{array}$ & $\begin{array}{c}0.69 * * * \\
(4.19)\end{array}$ & $\begin{array}{c}0.67 * * * \\
(4.23)\end{array}$ \\
\hline $\begin{array}{l}\text { Corruption } \rightarrow \text { Shadow } \\
\text { Economy }\end{array}$ & $\begin{array}{c}0.42 * * * \\
(2.64)\end{array}$ & $\begin{array}{c}0.43^{* * *} \\
(2.70)\end{array}$ & $\begin{array}{c}0.37 * * * \\
(2.27)\end{array}$ & $\begin{array}{c}0.47 * * * \\
(2.95)\end{array}$ & $\begin{array}{c}0.39 * * * \\
(2.50)\end{array}$ \\
\hline
\end{tabular}

Absolute z-statistics appear in parenthesis. $*=$ significance at $10 \%$ level, $* *$ significance at $5 \%$ level, $* * *=$ significance at $1 \%$ level.

Note: $\mathrm{SE}=$ shadow economy; $\mathrm{C}=$ corruption. 
With respect to the causes of corruption, we find a highly statistically significant coefficient for bureaucracy costs - which indicates that lower economic freedom increases corruption. In specification (4), school enrollment is used to proxy social causes of corruption, as is done in Treisman (2000). We find no evidence to support Treisman's argument that a more educated and literate population is less prone to corruption. While the coefficient for the rule of law is not statistically significant, the coefficient for government effectiveness is and has the theoretically expected sign. This means that countries with weaker quality of policy formulation and more political pressure on public policy have higher levels of corruption, ceteris paribus. We also consider fiscal freedom as cause of corruption and find that - as hypothesized - lower fiscal freedom increases corruption.

The indicator variables of corruption are fairly consistent across all model specifications and have the expected signs. Lower levels of real GDP per capita, i.e., lower levels of economic development, are associated with higher levels of corruption. The prevalence of bribery index shows that - as expected - a higher prevalence of bribery indicates a higher level of corruption. The variable capturing judicial independence is, however, not statistically significant. In specification (5), we substitute the variable measuring judicial independence for the freedom from corruption index for - which is, unfortunately, also not statistically significant.

Since our findings for both latent variables confirm the findings of earlier theoretical and empirical research, we consider interpreting the estimated coefficients of the mutual relationship between corruption and the shadow economy. Both coefficients - measuring the influence of the shadow economy on corruption and the influence of corruption on the shadow economy -are statistically significant and positive. The positive mutual relationship between corruption and the shadow economy is robust and stable across all estimated specifications. The structural equation model presents empirical evidence in support of the 
theoretical model presented in Echazu and Bose (2008). It does not support the model presented in Choi and Thum (2005) - in which corruption and the shadow economy are substitutes rather than complements.

Although the coefficients for corruption and the shadow economy are both positive, they differ substantially in magnitude. That is, the causal effect of the shadow economy on corruption is stronger than the effect of corruption on the shadow economy. One possible explanation for this is that corruption functions as an additional tax in the official economy which, in turn, increases the size of the shadow economy. Likewise, the shadow economy induces higher corruption as bureaucrats exploit their positions of power and as firms or individuals willingly pay bribes and hide their underground activities. In addition, the shadow economy can also be seen as an indication of overall deterioration of social and cultural norms, which results in even more widespread corruption.

\section{Summary and Conclusion}

This paper contributes to the debate about the relationship between corruption and the shadow economy using a structural equation model. We do not hypothesize whether the shadow economy and corruption are complements or substitutes, i.e., whether the shadow economy and corruption are positively or negatively related to each other. Rather, we test this relationship empirically.

Our findings reveal that a large shadow economy is linked to high levels of corruption. In countries with large shadow economies, firms and individuals often rely to a large extent on shadow economic activities. In order to avoid detection, taxation, and punishment, they bribe bureaucrats. Moreover, low tax revenues reduce the quality of public services and infrastructure. This in turn reduces the incentives to remain in the official economy. Weaker legal systems and unstable conditions for economic activity increase corruption. Acting like 
an extra tax corruption drives individuals underground. Thus, the empirical relationship between corruption and the shadow economy confirms the findings of Johnson, Kaufmann, and Shleifer (1997), Johnson, Kaufmann, and Zoido-Lobatón (1998b), Hindriks, Muthoo, and Keen (1999), and Friedman et al. (2000). Clearly, the structural equation model presented in this paper is only an additional step in furthering our understanding of corruption and the shadow economy.

\section{References}

Adam, Markus C. and Victor Ginsburgh (1985): The Effects of Irregular Markets on Macroeconomic Policy: Some Estimates for Belgium, European Economic Review 29(1), 15-33.

Bajada, Christopher and Friedrich Schneider (2005): The shadow economies of the AsiaPacific, Pacific Economic Review 10, 379-401

Bardan, P. (1997): Corruption and Development: A Review of Issues, Journal of Economic Literature 35, 1320-1346.

Bollen, Kenneth A. 1989. Structural equations with latent variables. Wiley.

Choi and Thum (2005): Corruption and the Shadow Economy, International Economic Review, 46, 817-836.

Dell’ Anno, Roberto and Friedrich Schneider (2003): The shadow economy of Italy and other OECD countries: What do we know?, Journal of Public Finance and Public Choice, 21/2-3, pp. 97-120.

Dell’ Anno, Roberto (2007): The shadow economy in Portugal: An analysis with the MIMIC approach, Journal of Applied Economics 10: 253-277. 
Dreher, Axel and Friedrich Schneider (2006): Corruption and the Shadow Economy: An Empirical Analysis, Paper presented at the 2006 Annual Meeting of the Public Choice Society, New Orleans, Louisiana, March 30-April 2, 2006.

Dreher, Axel, Christos Kotsogiannis, and Steve McCorriston (2005): How do Institutions Affect Corruption and the Shadow Economy?, University of Exter Discussion Paper.

Dreher, Axel, Christos Kosogiannis, and Steve McCorriston (2007):Corruption around the world: Evidence from a structural Model, Journal of Comparative Economics 35, 443446.

Easterly, W. and Ross Levine (1997): Africa’s growth tragedy: Policies and ethnic divisions. Quarterly Journal of Economics, 112, 1203-1250.

Echazu, Luciana and Pinaki Bose (2008): Corruption, Centralization, and the Shadow Economy, Southern Economic Journal, 75(2), 524-537.

Friedman, Eric, Simon Johnson, Daniel Kaufmann, and Pablo Zoido-Lobatón (2000): Dodging the grabbing hand: the determinants of unofficial activity in 69 countries, Journal of Public Economics, 76, 459-493.

Giles, David, E.A. (1998): The underground economy: Minimizing the size of government, Econometrics Working Paper 9801, Department of Economics, University of Victoria.

Giles, David, E.A., Lindsay, M. Tedds, and Gugsa Werkneh (2002): The Canadian underground and measured economies, Applied Economics, 34/4, pp. 2347-2352.

Goel, Rajeev K. and Michael A. Nelson (2005): Economic versus Political Freedom: CrossCountry Influences on Corruption, Australian Economic Papers 44(2), 121-133.

Gwartney, James and Robert Lawson, with Seth Norton (2008). Economic Freedom of the World: 2008 Annual Report. : The Fraser Institute. Data retrieved from www.freetheworld.com. 
Hillman, A.L. and M. Krausz (2004): Development failure, corruption, and the financial system. Paper presented at the European Public Choice Society Conference in Berlin, April 15-18.

Hindriks, J., A. Muthoo, and M. Keen (1999): Corruption, extortion and evasion, Journal of Public Economics, 74, 395-430.

Johnson, Simon, Daniel Kaufmann, and Andrei Shleifer (1997): The unofficial economy in transition, Brookings Paper on Economic Activity, 2, 159-221.

Johnson, Simon, Daniel Kaufmann, and Pablo Zoido-Lobatón (1998a): Regulatory discretion and the unofficial economy. The American Economic Review, 88/ 2, pp. 387-392.

Johnson, Simon, Daniel Kaufmann, and Pablo Zoido-Lobatón (1998b): Corruption, public finances and the unofficial economy. Discussion paper, The World Bank, Washington DC.

Kaufmann, Daniel, Aart Kraay, and Massimo Mastruzzi (2007): Governance Matters VI: Governance Indicators for 1996-2006, World Bank Policy Research, Working Paper WPS 4280.

Lippert, Owen and Michael Walker (eds.) (1997): The Underground Economy: Global Evidences of its Size and Impact, Vancouver: The Frazer Institute.

Loayza, Norman V. (1996): The Economics of the Informal Sector: A Simple Model and Some Empirical Evidence from Latin America, Carnegie-Rochester Conference Series Public Policy 45, 129-162.

Mauro, P. (1995): Corruption and growth. Quarterly Journal of Economics, 110, 681-712.

Mauro, P. (1998): Corruption and the composition of government expenditure, Journal of Public Economics 69, 263-279.

Miller, Terry, Kim R. Holmes, with Anthony B. Kim, Daniella Markheim, James M. Roberts, and Caroline Walsh (2008): 2008 Index of Economic Freedom, Washington, DC. 
Neck, Reinhard, Markus Hofreither, and Friedrich Schneider (1989): The Consequences of Progressive Income Taxation for the Shadow Economy: Some Theoretical Considertions, in Boes, Dieter and Bernhard Felderer (eds): The Political Economy of Progressive Taxation, Berlin: Springer, pp. 149-176.

North, D. (1990): Institutions, Institutional Changes and Economic Performance. Cambridge Univ. Press, Cambridge, UK

Paldam, M. (2003): The cross-country pattern of corruption: Economics, culture and the seesaw dynamics. European Journal of Political Economy, 18, 215-240.

Pasuk, P. and P. Sungsidh (1994): Corruption and Democracy in Thailand. The Political Economy Centre, Faculty of Economics, Bangkok.

Rose-Ackerman, S. (1999): Corruption and Government, Cambridge Univ. Press, Cambridge. Schneider, Friedrich (1986): Estimating the Size of the Danish Shadow Economy Using the Currency Demand Approach: An Attempt, Scandinavian Journal of Economics 88(4), 643-668.

Schneider, Friedrich (1997): The shadow economies of Western Europe, Economic Affairs, 17/3, pp. 42-48.

Schneider, Friedrich (2003): The shadow economy, in: Charles K. Rowley and Friedrich Schneider (eds.), Encyclopedia of Public Choice, Dordrecht: Kluwer Academic Publishers.

Schneider, Friedrich (2005): Shadow economies around the world: what do we really know?, European Journal of Political Economy, 21(3), September, pp. 598-642.

Schneider, Friedrich (2006): Shadow economies and corruption all over the world: what do we really know?, CESifo Working Paper No. 1806.

Schneider, Friedrich and Dominik Enste (2000): Shadow economies: Size, causes, and consequences, The Journal of Economic Literature, 38/1, pp. 77-114. 
Schneider, Friedrich and Dominik Enste (2002): The Shadow Economy: Theoretical Approaches, Empirical Studies, and Political Implications, Cambridge: Cambridge University Press.

Shleifer, Andrei and Robert W. Vishny (1993): Corruption, Quarterly Journal of Economics, 108, 599-618.

Smith, P. (1994): Assessing the size of the underground economy: the Canadian statistical perspectives, Canadian Economic Observer, Cat. No. 11-010, 3.16-33, at 3.18.

Tanzi, Vito (1998): Corruption around the world-causes, consequences, scope and cures. International Monetary Fund Staff Papers 45, 559-594.

Tanzi, Vito (1999): Uses and abuses of estimates of the underground economy, The Economic Journal, 109/456, pp. 338-340.

Transparency International (2009):

http://www.transparency.org/news_room/faq/corruption_faq, accessed 9 January.

Treisman, D. (2000): The causes of corruption: A cross-national study. Journal of Public Economics, 76, 399-457.

Thomas, Jim J. (1992): Informal Economic Activity, LSE, Handbooks in Economics, London: Harvester Wheatsheaf.

Van Rijckeghem, C. and Beatrice Weder (2001): Bureaucratic corruption and the rate of temptation: Do wages in the civil service affect corruption and by how much? Journal of Development Economics 65, 307-331.

World Bank (2008): World Development Indicators, CD-Rom, Washington DC.

World Bank (2009): Anticorruption, http://go.worldbank.org/K6AEEPROC0. 


\section{Appendix}

\section{Country list}

Algeria, Argentina, Australia, Bolivia, Brazil, Canada, Chile, Colombia, Costa Rica, Cyprus, Dominican Republic, Ecuador, Egypt, El Salvador, Ethiopia, Guatemala, Honduras, Iceland, India, Indonesia, Israel, Jamaica, Japan, Jordan, Madagascar, Malaysia, Mali, Malta, Mauritius, Mexico, Morocco, New Zealand, Nicaragua, Norway, Pakistan, Paraguay, Peru, Philippines, Singapore, South Africa, South Korea, Sri Lanka, Switzerland, Thailand, Trinidad and Tobago, Tunisia, Turkey, Uganda, United States, Uruguay, Venezuela. 
Table A.1. Data Sources and Definitions

Category Variable and Definition Source

Causes for the Shadow Economy

Economic Freedom Government consumption measured as general Gwartney, Lawson, and Taxation government consumption spending as a and Norton (2008) percentage of total consumption.

Transfers and subsidies as a share of GDP Gwartney, Lawson, measure the tax burden imposed by governments and Norton (2008) in order to provide transfers to others and the reduced freedom of individuals to keep what they earn.

Size of Government indicates the extent to Gwartney, Lawson, which countries rely on the political process to and Norton (2008) allocate resources, goods and services.

Regulation

Labor Market

\section{Labor market regulations measure the}

influence of standards such as minimum wages and dismissal regulations.

Business regulations measure the extent of unnecessary regulatory barriers and the administrative costs of doing business.
Gwartney, Lawson, and Norton (2008)

Gwartney, Lawson, and Norton (2008)

World Bank (2008) of the labor force that is without work but available for and seeking employment

Indicators of the Shadow Economy

Transaction

Measure
Ratio of the monetary aggregate M0 to the monetary aggregate M1 (Ratio of M0 to M1)
International

Monetary Fund

(IMF), International

Financial Statistics 
Activity

Labor force participation rate is the

proportion of the population ages 15-64 that is

economically active

Causes for Corruption

Political and Government effectiveness measures inter alia Kaufmann, Kraay,

Judicial Factors $\quad$ the independence of public services from and Mastruzzi (2007)

political pressures, the quality of policy

formulation, and the credibility of the

government's commitment to such policies.

The Rule of Law measures the extent to which

Kaufmann, Kraay, agents have confidence in and abide by the

and Mastruzzi (2007)

quality of contract enforcement, the police, and

the courts.

Social and Cultural Gross school enrollment is the ratio of total

World Bank (2008)

Factors enrollment, regardless of age, to the population

of the age group that officially corresponds to

the level of education shown.

Economic Factors Bureaucracy costs measure how stringent

Gwartney, Lawson, standards on product/service quality, energy and and Norton (2008) other regulations in a country are.

Fiscal freedom is the freedom of individuals

Miller et al. (2008)

and businesses to keep and control their income and wealth for their own benefit and use.

Indicators of Corruption

Economic

Real GDP per capita

World Bank (2008)

Development 
Measures of

Corruption
The index 'Extra payments / payment of

bribes ' indicates individuals’ perceptions about how common it is in a country that firms make undocumented extra payments or bribes.

Judicial independence shows if the judiciary in a country is independent from political influences of members of government, citizens, or firms.

Freedom from corruption index measures Miller et al. (2008) failures of integrity in the system, i.e. the distortion by which individuals are able to achieve personal gains at the expense of the general public. 
Table A.2. Corruption and Size of the Shadow Economy

\begin{tabular}{|c|c|c|c|}
\hline $\begin{array}{l}\text { Country Ranking } \\
(\mathrm{CPI})\end{array}$ & Country & CPI Country Score & $\begin{array}{l}\text { Shadow Economy } \\
\text { (\% of Official GDP) }\end{array}$ \\
\hline 1 & New Zealand & 9.5 & 12.5 \\
\hline 2 & Singapore & 9.3 & 13.6 \\
\hline 3 & Canada & 8.9 & 15.5 \\
\hline \multirow[t]{3}{*}{4} & Australia & 8.6 & 13.8 \\
\hline & Norway & 8.6 & 18.7 \\
\hline & Switzerland & 8.6 & 9.4 \\
\hline 7 & USA & 7.6 & 8.6 \\
\hline 8 & Chile & 7.5 & 20.6 \\
\hline 9 & Israel & 7.3 & 23.4 \\
\hline 10 & Japan & 7.1 & 11.0 \\
\hline 11 & Uruguay & 5.2 & 51.7 \\
\hline \multirow[t]{2}{*}{12} & Malaysia & 5.0 & 31.9 \\
\hline & Tunisia & 5.0 & 39.5 \\
\hline \multirow[t]{2}{*}{14} & Jordan & 4.7 & 21.1 \\
\hline & South Africa & 4.7 & 29.3 \\
\hline 16 & Costa Rica & 4.4 & 27.4 \\
\hline 17 & Brazil & 4.0 & 41.6 \\
\hline \multirow[t]{2}{*}{18} & Peru & 3.9 & 60.6 \\
\hline & Jamaica & 3.9 & 38.4 \\
\hline 20 & Colombia & 3.7 & 42.4 \\
\hline \multirow[t]{2}{*}{21} & Mexico & 3.6 & 32.6 \\
\hline & El Salvador & 3.6 & 47.7 \\
\hline
\end{tabular}




\begin{tabular}{|c|c|c|c|}
\hline & Sri Lanka & 3.6 & 46.6 \\
\hline 24 & Morocco & 3.5 & 37.5 \\
\hline 25 & Egypt & 3.4 & 36.5 \\
\hline \multirow[t]{2}{*}{26} & Dominican Republic & 3.3 & 33.8 \\
\hline & Turkey & 3.3 & 33.7 \\
\hline 28 & Thailand & 3.2 & 53.8 \\
\hline \multirow[t]{2}{*}{29} & Ethiopia & 3.0 & 41.8 \\
\hline & Mali & 3.0 & 44.3 \\
\hline 31 & Argentina & 2.9 & 28.0 \\
\hline \multirow[t]{2}{*}{32} & India & 2.7 & 24.9 \\
\hline & Philippines & 2.7 & 45.1 \\
\hline \multirow[t]{4}{*}{34} & Algeria & 2.6 & 35.3 \\
\hline & Guatemala & 2.6 & 52.2 \\
\hline & Honduras & 2.6 & 51.2 \\
\hline & Venezuela & 2.6 & 35.9 \\
\hline \multirow[t]{2}{*}{38} & Nicaragua & 2.5 & 47.6 \\
\hline & Pakistan & 2.5 & 38.3 \\
\hline \multirow[t]{3}{*}{40} & Ecuador & 2.2 & 35.9 \\
\hline & Bolivia & 2.2 & 68.3 \\
\hline & Madagascar & 2.2 & 41.0 \\
\hline 43 & Uganda & 2.1 & 45.1 \\
\hline 44 & Indonesia & 1.9 & 22.4 \\
\hline 45 & Paraguay & 1.7 & 30.3 \\
\hline
\end{tabular}

Note: The CPI Country Score and the shadow economy estimates, taken from Schneider (2006), are average values over the years 2001, 2002, and 2003. Cyprus, Iceland, Malta, Mauritius, South Korea, and Trinidad and Tobago are not displayed in the Table as no shadow economy estimates are available. 
Table A.3. Goodness-of-fit Measures

\begin{tabular}{lccccc}
\hline \hline Specification & $\mathbf{( 1 )}$ & $\mathbf{( 2 )}$ & $\mathbf{( 3 )}$ & $\mathbf{( 4 )}$ & $\mathbf{( 5 )}$ \\
\hline Chi-square & 97.23 & 97.36 & 92.14 & 99.03 & 93.19 \\
Degrees of Freedom & 81 & 81 & 81 & 81 & 81 \\
P-value & 0.11 & 0.10 & 0.19 & 0.08 & 0.17 \\
No. of Observations & 168 & 168 & 168 & 168 & 168 \\
Root Mean Squared Error of & 0.04 & 0.04 & 0.03 & 0.04 & 0.03 \\
Approximation (RMSEA) & & & & & \\
Goodness-of-fit Index (GFI) & 0.92 & 0.93 & 0.92 & 0.92 & 0.93 \\
Adjusted Goodness-of-fit Index & 0.90 & 0.90 & 0.91 & 0.90 & 0.90 \\
(AGFI) & & & & &
\end{tabular}

Note: The goodness-of-fit statistics for the estimated model specifications show an acceptable fit. If the model fits the data perfectly and the parameter values are known, the sample covariance matrix equals the covariance matrix implied by the model, i.e. $S=\Sigma(\theta)$. The null hypothesis of perfect fit corresponds to a p-value of 1 . Thus, the chi-square test of exact fit accepts all models. Also, the RMSEA is smaller than 0.05 in the specifications. Other measures such as GFI and AGFI also provide evidence of an acceptable fit. 